\title{
Detection of Taylorella equigenitalis and Taylorella asinigenitalis in horses in Croatia as a result of small scale survey
}

\author{
Zrinka Štritof ${ }^{1 *}$, Josipa Habušs ${ }^{1}$, Vesna Mojčec Perko ${ }^{1}$, Melita Majhut ${ }^{2}$, \\ Nika Brkljača Bottegaro ${ }^{3}$, Matko Perharić ${ }^{1}$, Suzana Hađina ${ }^{1}$, Zoran Milas ${ }^{1}$, \\ and Nenad Turk ${ }^{1}$ \\ ${ }^{1}$ Department of Microbiology and Infectious Diseases with Clinic, Faculty of Veterinary Medicine, \\ University of Zagreb, Zagreb, Croatia \\ ${ }^{2}$ Faculty of Veterinary Medicine, University of Zagreb, Zagreb, Croatia, student \\ ${ }^{3}$ Clinic of Surgery, Orthopedics and Ophthalmology, Faculty of Veterinary Medicine, University of Zagreb, \\ Zagreb, Croatia
}

\section{ŠTRITOF, Z., J. HABUŠ, V. MOJČEC PERKO, M. MAJHUT, N. BRKLJA ̌̌A BOTTEGARO, M. PERHARIĆ, S. HAĐINA, Z. MILAS, N. TURK: Detection of Taylorella equigenitalis and Taylorella asinigenitalis in horses in Croatia as a result of small scale survey. Vet. arhiv 87, 535-541, 2017.}

ABSTRACT

Contagious equine metritis (CEM) is a highly contagious venereal disease caused by the bacterium Taylorella equigenitalis. In Croatia, horses are almost never tested for this disease unless it is specifically requested. To date, no positive bacteriology results for T. equigenitalis have ever been obtained in Croatia. During 2014 and 2015, 12 animals were screened for T. equigenitalis using both bacteriology and a polymerase chain reaction (PCR) test. No positive cultures were obtained, however, samples from three animals tested positive on PCR. Sequencing of the PCR products revealed that one animal was positive for T. equigenitalis and two animals for T. asinigenitalis. These results represent the first evidence of T. equigenitalis and T. asinigenitalis infections in horses in Croatia. The high prevalence of T. equigenitalis and T. asinigenitalis positive horses $(\mathrm{n}=$ $3)$ in the population tested $(n=12)$ strongly suggests that the overall prevalence of horses positive for Taylorella spp. in Croatia is high, and that the equine population, especially those animals used for breeding, should be regularly tested for this bacterium. In addition, these results show the low sensitivity of using culture alone and that additional molecular methods should be utilised to identify positive cases of Taylorella spp.

Key words: horse, Taylorella equigenitalis, Taylorella asinigenitalis, Croatia

\footnotetext{
${ }^{*}$ Corresponding author:

Zrinka Štritof, Department of Microbiology and Infectious Diseases with Clinic, Faculty of Veterinary Medicine, University of Zagreb, Heinzelova 55, 10000 Zagreb, Croatia, Phone: +385 12390 200; Fax: +385 12390 207; E-mail: zstritof@vef.hr
} 


\section{Z. Štritof et al.: Detection of Taylorella spp. in horses in Croatia}

\section{Introduction}

Contagious equine metritis (CEM) is a highly contagious venereal disease caused by the bacterium Taylorella equigenitalis, a capnophilic, non-motile, small Gram-negative rod or pleomorphic coccobacillus (PLATT et al., 1977; RICKETTS et al., 1977). The disease was first described in the United Kingdom in 1977 (CROWHURST, 1977; PLATT and ATHERTON, 1977; TIMONEY et al., 1977). Subsequently, CEM has been found in many other countries in Europe and throughout the world (SWERCZEK, T. W., 1978; BLOBEL et al., 1979; HAZARD et al., 1979; KAMADA et al., 1981; MAY et al., 2012; RICKETTS et al., 2012). In stallions, T. equigenitalis is merely commensal, permanently colonizing specific sites on the external genitalia, without causing clinical signs (POWELL, 1981). Stallions therefore serve as a primary reservoir of this bacterium. In mares, T. equigenitalis infection may be subclinical or may manifest as endometritis, cervicitis and/or vaginitis, which results in temporary infertility (TIMONEY and POWELL, 1988). Mares may also develop a carrier state which can last from several months to years (HEATH and TIMONEY, 2008). Transmission of T. equigenitalis occurs mechanically during mating or via contamination upon semen collection. The rate of transmission via natural service exceeds that from either chilled or extended semen (SCHULMAN et al., 2013). A similar bacterium from the same genus, T. asinigenitalis, was first isolated from a donkey in 1997 (KATZ et al., 2000; JANG et al., 2001) and thereafter from a horse in 2004 (BAVERUD et al., 2006). The clinical relevance of $T$. asinigenitalis is currently unclear and is probably negligible (JANG et al., 2001; MEADE et al., 2010). However, due to their similar growth requirements, morphology and biochemical characteristics, it is important to differentiate $T$. asinigenitalis from $T$. equigenitalis. This can be achieved by using molecular methods, with species specific primers, preferably qPCR, which also increases test sensitivity and significantly shortens turnaround time (WAKELEY et al., 2006; MAY et al., 2016).

In Croatia, there is currently very little pre-breeding testing for T. equigenitalis in either mares or stallions, even as a part of any investigation into poor conception rates in mares. The objectives of this study were to screen a small population of equids for $T$. equigenitalis, to determine the prevalence of this disease in Croatia and to raise awareness of its presence in the general equine population, and more specifically, of the possible consequences for mare fertility.

\section{Materials and methods}

Samples. In 2014 and 2015, a total of twelve animals were tested (ten stallions and two mares). Samples from three stallions were submitted to the laboratory for prebreeding CEM testing requested by the owner, while samples from the other nine animals (seven stallions and two mares) were collected at the Faculty of Veterinary Medicine, University of Zagreb, Croatia, from stallions who were there for routine castration of 


\section{Z. Štritof et al.: Detection of Taylorella spp. in horses in Croatia}

stallions and during pre-breeding examinations of mares. In stallions, swabs (Nuova Aptaca SRL, Canelli, Italy) were obtained from four predilection sites: the distal urethra, the fossa glandis, the urethral sinus and the preputial folds. In mares, swabs were taken from two predilection sites: the clitoral fossa and the clitoral sinuses. Paediatric swabs (Copan Innovation, Brescia, Italy) were used for sampling of the clitoral sinus. Only one set of swabs was obtained from each animal. Immediately after collection, the swabs were transported in Amies transport medium with charcoal (Nuova Aptaca SRL, Canelli, Italy), to the laboratory under temperature - controlled conditions, and plated within 24 hours of collection.

Culturing. Culture was performed according to the OIE Manual of Diagnostic Tests and Vaccines for Terrestrial Animals (OIE, 2012). All swabs were inoculated onto two types of media: 1) chocolate agar with horse blood supplemented with antibiotics (clindamycin, trimetoprim sulfonamid, amfotericin B) as previously described (TIMONEY et al., 1982) and 2) chocolate agar with horse blood and the addition of amphotericin B $(10 \mathrm{mg} / \mathrm{mL})$. Inoculated plates were incubated in microaerophilic conditions (with addition of $7 \% \mathrm{CO}_{2}$ ) for 10 days, and examined on the $3^{\text {rd }}, 7^{\text {th }}$ and $10^{\text {th }}$ days of incubation. Used plates were simultaneously tested with control strains of $T$. equigenitalis and $T$. asinigenitalis.

Polymerase chain reaction (PCR) and sequence analysis. After plating, each swab was washed thoroughly with $500 \mu \mathrm{L}$ phosphate buffer saline (PBS), from which DNA was extracted from the suspension using a commercial kit (Qiagen, Netherlands) according to manufacturer's instructions. Primers targeting the 16S rRNA gene were used for PCR as previously described (BLEUMINK-PLUYM et al., 1994). The cycling conditions were as follows: denaturation: $30 \mathrm{~s}$ at $94{ }^{\circ} \mathrm{C}$; primer annealing: $15 \mathrm{~s}$ at $55^{\circ} \mathrm{C}$; and extension: $1 \mathrm{~min}$ at $72{ }^{\circ} \mathrm{C}$. PCR products were electrophoresed in $2 \%$ agarose gel and visualized with Gel Doc System (Bio-Rad, CA, USA). As the primers described by BLEUMINK-PLUYM et al., 1994 do not discriminate T. equigenitalis from T. asinigenitalis, products obtained by PCR were sequenced and analysed using Molecular Evolutionary Genetics Analysis software (MEGA 6.06). Sequence analysis of the 16S rRNA genes was used to differentiate $T$. equigenitalis from T. asinigenitalis, and to identify the Taylorella spp. (BAVERUD et al., 2006).

\section{Results}

All cultures were either negative or were contaminated before the end of the incubation period of ten days. In 3/12 (25\%) animals, a PCR product of 585 bp was obtained from at least one predilection site. The primers used, as described by BLEUMINK-PLUYM et al., 1994, amplify a product of 585 bp in Taylorella spp. positive samples. For practical purposes, the positive animals were assigned the letters A, B and C. Animal A was a stallion whose urethral fossa was positive, but the distal urethra and penile sheath were 


\section{Z. Štritof et al.: Detection of Taylorella spp. in horses in Croatia}

negative. Animal B was a stallion whose urethral fossa and distal urethra tested positive, while the penile sheath was negative. Animal $\mathrm{C}$ was a mare whose clitoral fossa and clitoral sinuses tested positive. These results are summarized in Table 1. All bands correlated with the positive controls, as well as with the adequate size of the molecular marker (Fig. 1). Sequence analysis of the PCR products revealed that of the three positive animals, one was positive for T. equigenitalis (animal A) and two for T. asinigenitalis (animals B and C).

Table 1. Summarized results for the three Taylorella sp. positive animals

\begin{tabular}{|l|c|c|c|c|c|}
\hline & Clitoral fossa & Clitoral sinuses & Urethral sinus & Urethral fossa & Distal urethra \\
\hline $\begin{array}{l}\text { Animal A } \\
\text { (stallion) }\end{array}$ & Not applicable & Not applicable & Negative & Positive & Negative \\
\hline $\begin{array}{l}\text { Animal B } \\
\text { (stallion) }\end{array}$ & Not applicable & Not applicable & Negative & Positive & Positive \\
\hline $\begin{array}{l}\text { Animal C } \\
\text { (mare) }\end{array}$ & Positive & Positive & Not applicable & Not applicable & Not applicable \\
\hline
\end{tabular}

\section{Discussion}

Interestingly, the animals that tested positive for Taylorella spp. had rarely been bred and none of them had had any contact with donkeys. Animal A was a warmblood stallion that had been bred only once, several years before. Animal B was a coldblood stallion that had been bred three times, and animal $\mathrm{C}$ was a warmblood mare whose reproductive history was unknown to the owner, but she had not been bred for at least three years prior to sampling. In all three animals it was impossible to determine the source of infection. Nine in-contact animals from the same premises as the positive animals all tested negative for Taylorella spp.

In Croatia, equine reproductive problems, both in terms of low conception rates and abortions, are rarely adequately addressed or their cause investigated. Despite the fact that all expenses incurred during the investigation of an abortion are covered by the Government, horse owners are still reluctant to report an abortion to a veterinarian. This is probably due to the fact that in cases where an infectious cause is determined, the owners are required to carry out mandatory disease control measures, including transport restrictions. In most cases where an abortion is reported, only samples for serology from the mare are submitted. Therefore, viral causes of reproductive disorders such as Equine Herpes Virus and Equine Arteritis Virus are readily diagnosed. After abortion, mares are also tested for leptospirosis, which forms an integral part of an abortion diagnostics panel (TURK et al., 2013). Nevertheless, evidence of other bacterial causes of reproductive problems in horses is scarce. The findings from our study strongly suggest 


\section{Z. Štritof et al.: Detection of Taylorella spp. in horses in Croatia}

that $T$. equigenitalis could be a cause of the low conception rates seen in Croatian horses (PRVANOVIĆ et al., 2008).

The fact that we detected $T$. equigenitalis in such a small sample size is concerning. It indicates that the overall prevalence of T. equigenitalis infection in horses in Croatia may be high and requires further investigation of a larger sample size.

T. asinigenitalis was detected in 2/12 (16\%) animals. Although the clinical relevance of $T$. asinigenitalis is currently unknown and probably negligible (JANG et al., 2001), awareness of its presence in the Croatian equine population is relevant in order to distinguish it from $T$. equigenitalis during diagnostic testing.

\section{Conclusion}

In conclusion, considering the control measures for CEM instituted in most European countries and the ever increasing transportation of horses, both nationally and internationally, it would be beneficial to have an insight into the epidemiological status of this disease in Croatia. Our findings highlight the need for the implementation of surveillance and control measures for CEM in Croatia. Aa a minimum, mandatory testing of all licensed stallions in Croatia should be introduced in order to estimate disease prevalence, minimise reproductive loss and to prevent the further spread of this disease.

\section{Acknowledgements}

The authors would like to thank Irena Zdovc from the Institute of Microbiology and Parasitology, Veterinary Faculty, University of Ljubljana, Slovenia, for her highly appreciated advice and suggestions and also Petra Pavečić for her excellent technical assistance.

\section{References}

BAVERUD, V., C. NYSTRÖM, K. E. JOHANSSON (2006): Isolation and identification of Taylorella asinigenitalis from the genital tract of a stallion, first case of a natural infection. Vet. Microbiol. 116, 294-300.

BLEUMINK-PLUYM, N. M. C., M. E. B. WERDLER, D. J. HOUWERS, J. M. PARLEVLIET, B. COLENBRANDER, B. A. M. VAN DER ZEIJST (1994): Development and evaluation of PCR test for detection of Taylorella equigenitalis. J. Clin. Microbiol. 32, 893-896.

BLOBEL, H., J. BRÜCKLER, D. KITZROW, K. BLOBEL (1979): Contribution to the knowledge of contagious equine metritis in the Federal Republic of Germany. Comp. Immunol. Microbiol. Infect. Dis. 2, 551-554.

CROWHURST, R. C. (1977): Genital infection in mares. Vet. Rec. 100, 476.

HAZARD, G. H., K. L. HUGHES, P. J. PENSON (1979): Contagious equine metritis in Australia. J. Reprod. Fertil. Suppl. 27, 337-342. 


\section{Z. Štritof et al.: Detection of Taylorella spp. in horses in Croatia}

HEATH, P., P. TIMONEY (2008): Contagious Equine Metritis. 838-844 In O.I.E. Manual for Diagnostic Tests and Vaccines for Terrestrial Animals, $6^{\text {th }}$ ed. Office International des Epizooties, Paris, France, pp. 838-844.

JANG, S. S., J. M. DONAHUE, A. B. ARATA, J. GORIS, L. M. HANSEN, D. L. EARLEY, P. A. VANDAMME, P. J. TIMONEY, D. C. HIRSH (2001): Taylorella asinigenitalis sp. nov., a bacterium isolated from the genital tract of male donkeys (Equus asinus). Int. J. Syst. Evol. Microbiol. 51, 971-976.

KAMADA, M., Y. AKIYAMA, T. ODA, Y. FUKUNAGA (1981): Contagious equine metritis: isolation of Haemophilus equigenitalis from horses with endometritis in Japan. Jpn. J. Vet. Sci. 43, 565-568.

KATZ, J. B., L. E. EVANS, D. L. HUTTO, L. C. SCHROEDER-TUCKER, A. M. CAREW, J. M. DONAHUE, D. C. HIRSH (2000): Clinical, bacteriologic, serologic, and pathologic features of infections with atypical Taylorella equigenitalis in mares. J. Am. Vet. Med. Assoc. 216, 1945-1948.

MAY, C. E., M. L. SCHUlmAN, C. GERSTENBERG, A. GROBLER, A. MPHELE, A. J. GUTHRIE (2012): Confirmation of the first outbreak of contagious equine metritis in South Africa. In: $9^{\text {th }}$ International Conference on Equine Infectious Diseases. (Squires, E. L., J. A. Orsini, J. Evans, Eds.). Equine Vet. Sci. 32, 77.

MAY, C. E., A. J. GUTHRIE, B. KEYS, C. JOONE, M. MONYAI, M. L. SCHULMAN (2016): Polymerase chain reaction-based national surveillance programme to determine the distribution and prevalence of Taylorella equigenitalis in South African horses. Equine Vet. J. 48, 307-311.

MEADE, B. J., P. J. TIMONEY, J. M. DONAHUE, A. J. BRANSCUM, R. FORD, R. ROWE (2010): Initial occurrence of Taylorella asinigenitalis and its detection in nurse mares, a stallion and donkeys in Kentucky. Prev. Vet. Med. 95, 292-296.

OIE (2012): OIE Manual of Diagnostic Tests and Vaccines for Terrestrial Animals, Chapter 2.5.2, Contagious Equine Metritis version adopted in May 2012. http://www.oie.int/fileadmin/Home/ eng/Health_standards/tahm/2.05.02_CEM.pdf

PLATT, H. J., G. ATHERTON (1977): Contagious equine metritis. Vet. Rec. 101, 434.

PLATT, H. J., G. ATHERTON, D. J. SIMPSON, C. E. TAYLOR, R. O. ROSENTHAL, D. F. J. BROWN, T. G. WREGHITT (1977): Genital infection in mares. Vet. Rec. 101, 20.

POWELL, D. G. (1981): Contagious equine metritis. Adv. Vet. Sci. Comp. Med. 25, 161-184.

PRVANOVIĆ, N., M. CERGOLJ, M. ČAČIĆ, A. GAŠPAR, S. HORVAT, J. GRIZELJ, I. GETZ, M. SAMARDŽIJA, T. DOBRANIĆ (2008): Influence of breed, parity and age on reproductive efficiency and conception rate of mares. Proceedings of the $4^{\text {th }}$ Croatian Veterinary Congress, 5-8 November, 2008, Šibenik, Croatia, pp. 239-245.

RICKETTS, S. W., P. D. ROSSDALE, N. J. WINGFIELD-DIGBY, M. M. FALK, R. HOPES, M. D. N. HUNT, C. K. PEACE (1977): Genital infection in mares. Vet. Rec. 101, 65.

RICKETTS, S. W., J. CROWHURST, R. NEWTON, N. GIBBENS (2012): Contagious equine metritis organism confirmed in Gloucestershire. Vet. Rec. 170, 398. 


\section{Z. Štritof et al.: Detection of Taylorella spp. in horses in Croatia}

SCHULMAN, M. L., C. E. MAY, B. KEYS, A. J. GUTHRIE (2013): Contagious equine metritis: artificial reproduction changes the epidemiologic paradigm. Vet. Microbiol. 167, 2-8.

SWERCZEK, T. W. (1978): Contagious equine metritis in the USA. Vet. Rec. 102, 512-513.

TIMONEY, P. J., J. WARD, P. KELLY (1977): A contagious genital infection of mares. Vet. Rec. $101,103$.

TIMONEY, P. J., S. J. SHIN, R. H. JACOBSON (1982): Improved selective medium for isolation of the contagious equine metritis organism. Vet. Rec. 111, 107-108.

TIMONEY, P. J., D. G. POWELL (1988): Contagious equine metritis - epidemiology and control. J. Equine Vet. Sci. 8, 42-46.

TURK, N., Z. MILAS, J. HABUŠ, Z. ŠTRITOF MAJETIĆ, V. MOJČEC PERKO (2013): Equine leptospirosis in Croatia - occurrence of subclinical infections and abortions. Vet. arhiv 83, 253-262.

WAKELEY, P. R., J. ERRINGTON, S. HANNON, H. I. ROEST, T. CARSON, B. HUNT, J. SAWYER, P. HEATH (2006): Development of a real time PCR for the detection of Taylorella equigenitalis directly from genital swabs and discrimination from Taylorella asinigenitalis. Vet. Microbiol. 118, 247-254.

Received: 27 June 2016

Accepted: 20 January 2017

\section{ŠTRITOF, Z., J. HABUŠ, V. MOJČEC PERKO, M. MAJHUT, N. BRKLJAČA BOTTEGARO, M. PERHARIĆ, S. HAĐINA, Z. MILAS, N. TURK: Dokaz bakterija Taylorella equigenitalis i Taylorella asinigenitalis u konja u Hrvatskoj. Vet. arhiv 87, 535-541, 2017.}

SAŽETAK

Do sada u populaciji konja u Republici Hrvatskoj nije potvrđena prisutnost bakterija iz roda Taylorella što je vjerojatno posljedica malog broja pretraženih uzoraka i toga što su do 2014. godine životinje pretraživane samo bakteriološkom pretragom. Tijekom 2014. i 2015. godine pretraženo je 12 životinja, i to bakteriološkom pretragom i lančanom reakcijom polimerazom (PCR). Bakteriološka pretraga svih uzoraka bila je negativna, no molekularna pretraga bila je pozitivna za uzorke podrijetlom od tri životinje. Sekvenciranjem produkata dobivenih lančanom reakcijom polimerazom (PCR) utvrđeno je da je jedna od tri pozitivne životinje bila pozitivna na bakteriju Taylorella equigenitalis, a ostale dvije životinje na bakteriju Taylorella asinigenitalis. To je prvi dokaz ovih bakterija u Republici Hrvatskoj. Činjenica da su, od svega 12 pretraženih životinja, tri životinje bile pozitivne, upućuje na to da bi pojavnost infekcija ovim bakterijama u populaciji konja mogla biti relativno visoka. Za procjenu pojavnosti potrebno je pretražiti mnogo veći broj životinja. Nadalje, dokazana prisutnost bakterije Taylorella equigenitalis upućuje na to da je preporučljivo pretraživati rasplodne životinje prije pripusta. Rezultati također potvrđuju zapažanja drugih autora da je, uz bakteriološku pretragu, životinje preporučljivo pretražiti i molekularnim metodama dijagnostike.

Ključne riječi: konj, Taylorella equigenitalis, Taylorella asinigenitalis, Hrvatska 
